\title{
PREVENTING CHILD MARRIAGE: THE ROLE OF STRATEGIC ACTORS IN SOUTH KALIMANTAN
}

\section{Vinita Susanti, $\left({ }^{(}\right)$Reni Kartikawati, $\left({ }^{*}\right)$ Irwan M Hidayana, $\left({ }^{3}\right)$ Ida Ruwaida, $\left({ }^{4}\right)$ Lusiana Rumintang $\left({ }^{5}\right)$}

${ }^{1}$ Department of Criminology, Faculty of Social and Political Sciences, University of Indonesia, Depok, Indonesia.

${ }^{2}$ Gender and Sexuality Study Unit, LPPSP Faculty of Social and Political Sciences, University of Indonesia, Depok, Indonesia.

${ }^{3}$ Department of Anthropology, Faculty of Social and Political Sciences, University of Indonesia, Depok, Indonesia.

${ }^{4}$ Department of Sociology, Faculty of Social and Political Sciences, University of Indonesia, Depok, Indonesia,

${ }^{5}$ Doctoral Program Student of Anthropology Department, Faculty of Social and Political Sciences, University of Indonesia, Depok, Indonesia

\section{ARTICLE INFORMATION \\ Submitted $\quad: 24^{\text {th }}$ March, 2021 \\ Review $: 15^{\text {th }}$ April, 2021 \\ Accepted $:: 11^{\text {th }}$ May, 2021 \\ Published : : $07^{\text {th }}$ June, 2021 \\ Available Online : June, 2021}

\section{KEYWORDS}

Child marriage; child protection; gender justice; strategic actors; SRHR.

\section{CORRESPONDENCE}

E-mail:vinita.susanti@ui.ac.id

\begin{abstract}
A B S T R A C T
South Kalimantan Province is the province with the highest number of child marriage cases, according to data from the Central Statistics Agency (BPS) in 2017 and 2019. This has resulted in various negative impacts, one of which is the high maternal mortality rate, as well as the low human development index $(H D I)$ in the province, which is placed at the 22nd position from 34 provinces in Indonesia. This paper aims to examine various strategic actors who can prevent and reduce the practice of child marriage in South Kalimantan Province in three levels of analysis: the macro, mezzo, and micro levels. This paper seeks the relationship between the three aspects of structure, culture, and social processes at the three macro, mezzo, and micro levels, as the concept of analysis used to prevent child marriage practices from a child protection perspective and SRHR issues. This study uses a qualitative approach through in-depth interview methods to key policy makers and is supported by focus group discussions (FGD) to participants in discussions from various backgrounds, both government agencies, and non-governmental organizations concerned with the issue of child and women's protection in South Kalimantan Province.
\end{abstract}

\section{A. INTRODUCTION}

T here was also a girl who was 'compelled' to marry because of an 'accident' (pregnancy), and then divorced after the wedding. The man divorced her, who returned to be a burden on her parents." One of the stories collected in the study titled "A Qualitative Study on Causal Factors and Consequences of Divorce After Child Marriage in Sukabumi, Rembang, and West Lombok Districts," conducted by the Center for Gender and Sexuality Studies, FISIP UI (2017), describes how girls become the most vulnerable victims of the practice of child marriage (Benedicta et al., 2017). One of the factors causing child marriage is generally young women experiencing unwanted pregnancies outside the marital relationship. Several other factors that cause child marriage are economic factors and poverty (dropping out of school, paying parents' debts, reducing family burdens), religious factors (to avoid adultery), cultural factors (better to marry young rather than becoming a spinster), and adolescents' ignorance of their reproductive health and sexuality (Pakasi, 2018).

Statistically, based on data from SUSENAS (Badan Pusat Statistik, 2016), it shows that 1 in 9 girls get married before the age of 18 , or the equivalent of 375 girls getting married each day. The data have put Indonesia in the 7th position in the world in the number of cases of child marriage under 18 years (Statistik \& UNICEF, 2016). Data from the Central Bureau of Statistics for 2017 also shows that the prevalence of child marriage in Indonesia in 2015 was 23\%, (Badan Pusat Statistik, 2017). Meanwhile, there are 20 provinces with a higher prevalence of child marriage 
than the national average (22.82\%). The three provinces with the highest number of cases of child marriage are South Kalimantan at $39.53 \%$, Central Kalimantan at $39.21 \%$, and Bangka Belitung Islands at 37.19\% (Badan Pusat Statistik, 2017).

The results of the meta research "Reconstruction of Social and Political Interpretations of Child Marriage" (Hidayana, 2018) confirmed the findings of these statistical data. Analysis of 60 research results on child marriage in the last 10 years (2007-2017) in the form of books, book chapters, bachelor theses, theses, scientific journal articles, and research reports, concludes that: (1) Child marriage occurs due to a number of factors, namely economy, religion, customs, weak marriage laws, gender and sexuality disparities; (2) Child marriage is not seen as a social problem so that it does not require efforts to prevent it; (3) The impact of child marriage is not only felt by girls who become married, but also affects the family and community. In families, child marriage does not necessarily ease the burden on parents, in fact, it is often burdensome because the economic conditions of the child's family are not yet established. Especially if there is a divorce, the daughter will return to her parents' house. For the community, child marriage can have an impact on population problems, continuing poverty, low quality of human resources and low productivity; (4) Local policies to prevent child marriage are still limited to a few areas. From a legal standpoint, a number of parties admit that the Marriage Law No.1 of 1974, which regulates the minimum age for marriage, needs to be amended; (5) The practice of child marriage requires cultural intervention through reconstruction of social and political interpretations.

The explanation above shows that the practice of child marriage in Indonesia shows an alarming number of cases and impacts. For this reason, the role of the state, in this case the governments at the central and provincial levels, down to the district and village levels, as well as all elements of society, including families (parents/guardians), are required to take responsibility for the implementation of child protection. In this case, this means the prevention of the practice of child marriage, because it violates children's rights, as stated in the 1986 Convention on the Rights of the Child, Presidential Decree No. 36 of 1990 concerning the CRC, and Law No. 35 of 2014 concerning Amendments to Law No. 23 of 2002 concerning Child Protection.

Observing the results of meta research on to the issue of child marriage, which has different points of view from several fields of study, including health, child protection, social and cultural issues, gender-based violence, anthropology, criminology, sociology and others, it can be said that there have been many lessons learned from the results of studies examining the issue of child marriage in various social and regional backgrounds in Indonesia. However, what must be questioned is why these studies have not significantly changed or reduced the number of child marriage cases in Indonesia. This article is part of the results of a meta-research study titled "Reconstruction of a Socio-Political Interpretation of Child Marriage". Specifically, this article aims to examine the issue of child marriage in the light of child protection, and the issue of sexuality and reproductive health rights (SRHR) by looking at the role of strategic actors in Banjarmasin City, South Kalimantan Province, who can change and prevent child marriage in three levels of analysis, namely the macro, mezzo, and micro levels. South Kalimantan Province was selected as the object of study, because it ranks the highest of 34 provinces in Indonesia on the practice of child marriage (Badan Pusat Statistik, 2017).

\section{B. METHOD}

$\mathrm{T}$ he data in this study were collected using qualitative research methods, through primary data collection, in-depth interviews with key policy stakeholders (DPRD Commission 4 and Bappeda of South Kalimantan Province), as well as representatives of non-governmental organizations (NGOs) that are active in child protection issues, such as Aisyiyah and the Child Protection Agency. In addition to in-depth interviews, focus group discussions (FGD) were also conducted with government agencies related to child protection issues and the practice of child marriage, represented by the Provincial DP3A and the Provincial Office of the Ministry of Religion, and other non-governmental organizations (Children's Forum, PKK, PKBI, PGRI, Indonesian Teachers Association, Population Coalition) in South Kalimantan Province. Meanwhile, this article also draws secondary data from the BPS, previous studies, as well as existing policy documents at the level of South Kalimantan Province, particularly Banjarmasin City. The method used, in the end, intends to explore the roles of strategic actors in preventing the practice of child marriage within the framework of the concept of child protection seen from three aspects of structure, culture and social processes. 


\section{RESULTS AND DISCUSSION}

$\mathrm{n}$ the results and discussion section, this article focuses on two discussions, namely first, an explanation of the practice of child marriage in terms of structure, culture and social processes, especially in the perspective of child protection, and second, the role of strategic actors in preventing child marriage at the macro, mezzo and micro levels.

\section{Child Marriage in the Child Protection Perspective seen in the Aspects of Structure, Culture and Social Process}

Review of existing literature records two patterns of child marriage, namely girls marrying grown-up men, or girls marrying boys of a similar age, both of which are decided by the parents as the party with the decision making role in child marriage.

In the Indonesian context, structural and cultural factors are the background for the practice of child marriage. Based on Yulkardi (2020) Sialang residence used Tigo Sapilin cord as way of life including marriage as solution of sex before married and unplanned pregnancy. But then in reality it give idea of disfunction and disruption of its own fuction to help the child, as Merton theory state in disfunctional theory. The disfuction then open new idea of Doro, another way of punishing the act of sex before marriage. Yulkardi believed doro is another paradox of disfuction of 3 institution, adat, religion, and governemnt. Another researched by Wulandari (2020) about how Simbur Cahaya Law in Palembang Sultane is used in every human relation such as the marriage of the citizen including child. In this law state how they punished people who get pregnancy out of marriage to be wedded and payed fine, and if the men is missing, the pregant woman should be secluded for 3 years as punishment.

In particular, there are two studies on the practice of child marriage in South Kalimantan province. First, research by Fauziah in (Kustini, 2013) which shows that since 2010, according to the Basic Health Research (Riskesdas), the rate of child marriage in South Kalimantan was quite high, namely the number of couples who marry at the age of under 15 has reached $9 \%$. This shows that the practice of child marriage in South Kalimantan was above the national average of only $4.8 \%$. According to the Head of the South Kalimantan Provincial Health Office, this high number was caused by economic and cultural factors, unwanted pregnancy, technological sophistication, teenage interactions, and the inability to continue with higher education, so that many students chose to get married (Kustini, 2013). Furthermore, in the results of this study it is also stated that the practice of child marriage was also the background of the many cases of unrecorded marriages (Fauziah in Kustini, 2013). The second study was conducted by the Center for Gender and Sexuality Studies in 2014 which states that there are several factors behind the case of child marriage in South Kalimantan, namely poverty, traditions/customs, wrong understanding of religion, lack of education, and risky sexual behavior. In this case these factors cause the impacts of child marriage, such as economic, social, health, psychological impacts and sustainability of education (Djamilah dan Kartikawati., 2014).

Observing Article 1 paragraph 2 of the Child Protection Law Number 34 of 2014, it is stated that "Child protection is all activities to guarantee and protect children and their rights so that they can live, grow, develop and participate, optimally in accordance with their dignity and humanity, and receive protection from violence and discrimination". Child protection is an effort to prevent and respond to violence, exploitation, abuse and neglect of children.

In relation to the practice of child marriage, there are three aspects that can play a role in solving the problem of child marriage in society, so that the community plays an active role in protecting the interests of children. These three aspects, namely, structure, culture, and social processes, are as follows:

Figure 1. Socio-Cultural Transformation: Structure Culture, Process

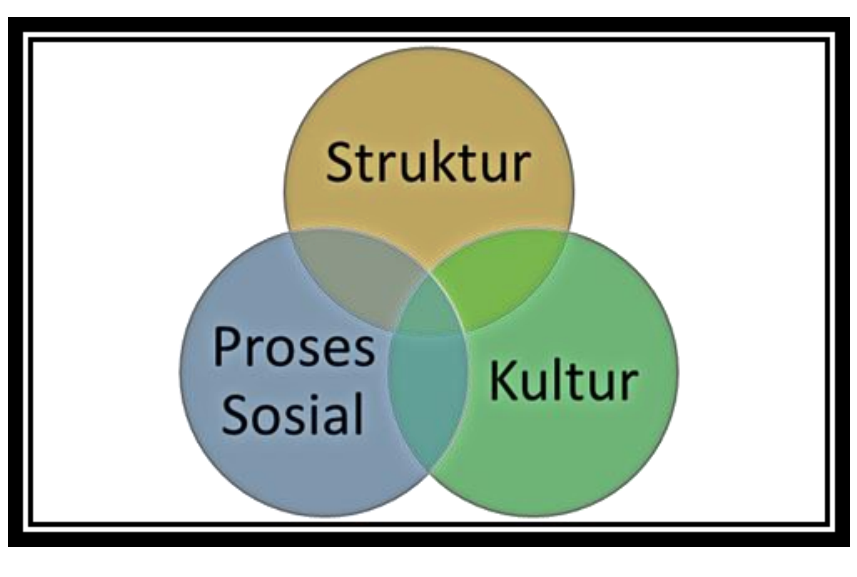

Source: (Wirutomo, 2014)

Referring to the picture above, social transformation includes 3 (three) aspects:

- Structure, namely in the form of changes in society towards a gender-just order, including being supported by policies and institutions that are gender responsive. Various formal and 
non-formal policies are "binding" and "compelling", in an effort to improve the structure that is exclusive (unfair, discriminatory) to be inclusive (fair, provides equal rights).

- Culture, namely all value systems, norms, beliefs and all habits and customs that have been ingrained (internalized) in an individual or society so that they have "power" to shape behavior patterns and attitudes of community members (from within). In the context of human development and its participation in development, it is necessary to improve the quality of norms and values in social institutions that produce a pattern of social relations that is gender-equitable and equal. More than the quality of a value system, customs can promote the welfare of the people. The approach can be direct (through socialization, education, etc.) or indirect (as role models).

- Social processes, namely the dynamics of everyday interaction between a member of the public in efforts of structural and cultural development. Through a dynamic and creative social process, individuals and groups can express their aspirations relatively freely, carry out negotiations between members of the community. This arena can be a place for people to negotiate an existing order so that it becomes a source of changes in the existing (unjust) structure and culture. In this context it is empowering to be part of the social process, both at the individual level in the form of a substantive empowerment agent, even transformative (human resources including mindset/value etc.). Empowerment at the collective level is in the form of organizing collective action which will later become the basis for strengthening social and political capital. The last is empowerment at the institutional level, namely the involvement of various strategic social institutions: family, peer groups, mass media, education, religion, politics, and others.

Thus, it is necessary to develop an agenda for social transformation by prioritizing the principle of synergy of various elements of civil society and its organizations, even the mass media. In the context of child marriage, this synergy is needed in an effort to build policies that have the paradigm of protecting and causing welfare for children, and with a gender justice perspective, including the level of policy and implementation in South Kalimantan Province, for example through the roles of various strategic actors.

\section{The Role of Strategic Actors in Preventing Child Marriage at the Macro, Mezzo and Micro Levels}

The role of strategic actors in preventing child marriage in South Kalimantan will be analyzed at 3 (three) levels, namely macro, mezzo and micro. For the level of macro analysis, the structure and culture of the people of West Kalimantan, specifically Banjarmasin City, which is a location associated with the issue of child marriage, will be explained, as well as the relationship between strategic actors at the macro level and those at the mezzo level. The data were obtained from in-depth interviews with the chairman of the DPRD Commission 4 and the Chairperson of the South Kalimantan Provincial Bappeda.

For the level of mezzo analysis, what will be analyzed is the moderating agent in the relations between strategic actors at the macro level and those at the micro level: how strategic actors at the macro level are related to the mezzo level, and how strategic actors in the mezzo level are related to the micro level. Data were obtained from FGDs and in-depth interviews with both government and non-government institutions actively involved in child protection issues.

At the micro level, what will be analyzed are the strategic actors in the family where the decision to carry out child marriage is made: how strategic actors at the mezzo level and strategic actors at the micro level are related.

Figure 2. Levels of Analysis of Strategic Actors in Preventing Child Marriage

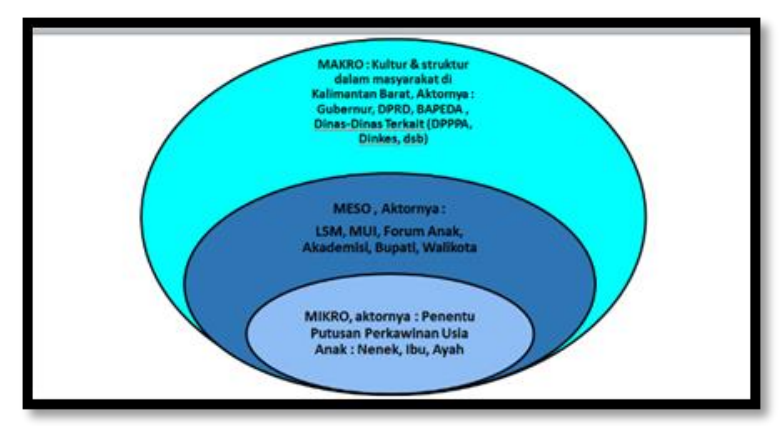

Source: processed from research data, 2018

Methodologically, analysis is carried out by studying secondary data, from existing regulations or publications, relating to child marriage in South Kalimantan Province. With the diversity of data obtained from various levels, the role of strategic actors 
in preventing child marriages can be explained. As previously explained in Child Protection Law Number 35 of 2014 , children must be protected. In this case, the parties who play a role in child protection efforts are stated in Article 20, namely "State, Government, Local Government, Community, Family, and Parents or Guardians are obliged and responsible for the implementation of Child Protection". However, in the case of child marriage, it appears that children's rights are neglected, such as the right to education, the right to play, as well as the growth and development of children because the children are 'forced' to live as a household. Whereas the role of strategic actors in this case as agents of social transformation should be able to play a role in solving the problem of child marriage in society. The following is an explanation of strategic actors in preventing child marriage according to their level.

\section{- Macro Level}

The roles of strategic actors in the macro level are obtained from interviews and focus group discussions (FGD) of key stakeholders in South Kalimantan. Based on the interview in can conlude that they are aware of the high number of child marriage in their area. As the issue is up on 2018 Development Planning Deliberations (Musrenbang) and were discussed as strategic plan on province level. But then the issue only ended up as socialization in academic level, regional government, and community organization that concerned in the area, where they need it is to touch the grassroot of the problem, the village where the child lives. Children's Voice of South Kalimantan as one of the stakeholder said both in 2017 and 2018 they already state that childres is actually aware of occuring child marriage in their area, but there is no immidiate action to protect the children. Banjarmasin as one of the regency in South Kalimantan province states they already have child-friendly police but it said it is ineffective as it's not reach all cities.

Government Representative (Bappeda) in FGD state prevention matters was held because of lack of policies at the implementation level. They explain that prevention of child marriage has not been budgeted yet and has not become a priority issue at this time, even though the number of cases is quite high. Bappeda elaborate more child protection policies are already budgeted but then it's not distributed evenly, they explain its because south kalimantan is wide and geographically quite far, so it only reaches at provincial level. As for now, The predominant local culture of the communities, such as marrying off children after they have reached puberty (when girls have begun to menstruate, and boys have wet dreams), or for reasons of economic factors (as part of a way of easing the burden of family economy), and due to having dropped out of school, make the practice of child marriage considered the best solution for those who do not understand the impact of child marriage. What need it is the formation of policies such as Regional Regulation (Perda) and Mayor/District Head/Governor Regulations to be used as legal umbrella for policies and budgeting for each agency, to work programs in village/district governments. Another thing that is needed is Cooperation between stakeholders from the provincial level to districts/cities. All of this to give best solialization channel about impact of child marriage from provincial level, disctricts/cities level, to the most important, village level.

\section{- Mezzo level}

Meanwhile, at the mezzo level, in South Kalimantan Province, the role of strategic actors can be seen from the roles of schools, religious figures (Ustad and Ustadzah), community leaders (Village Heads, Hamlet Heads, RT/RW) and related institutions or agencies (KUA/Religious Court/Civil Registry/Women Empowerment and Child Protection Services, and others) at the village/city/district level, as well as community social organizations (NGOs) that care about the issues of women's empowerment and child protection. Based on FGD, the following are elaborating how each of the organizations hold a position to flow the information to the smallest level of society, the grassroot of this problem. The following provides an elaboration:

1. The role of the school is about educating the child, providing a comfortable, safe, and happy environment. There are two things school can take to help the child, first educate about sexual and reproductive health as well as the negative impact of child marriage, also educate about child protection law about child marriage. Both of them to educate the child how marriage will impact their physical and psychological. This hope the child can advocate and reject when their parents want to marry them off. School also need to educate the parents about this impact. One of the aim is to reduce school drop out. Role of Religious Leaders.

2. Religious leaders are believed to become impactful people to relay the message. If in nationwide and province have Indonesian Ulama Council (MUI) then in community they have Ustad and Ustadzah (a term for religious leaders in general). They can rely the massage about child marriage through several forums, such as friday khutbah, routine recitation event, even simple gathering after praying. Ustadzah (woman prefix) even can use house to house and Taklim Assembly (a small gathering). Intervention can be carried out by reducing under-hand marriage or 'village marriage' (kawin siri) as it is usually done using religion

114 | P a g e

https://doi.org/10.25077/jantro.v23.n1.p110-117.2021 
procedures. However, there are still religious leaders who think that young age marriage (that children can be married off when they reach puberty) is one of the alternatives to prevent dating or adultery. This problem needs another advocacy process by another stakeholder, community and nationwide.

3. Role of Community Leaders. Community leaders such as village head, sub-district head, and other several other figures surely have impact in the community. They can make policies that aim to create a child-friendly city. The most obvious example associated with this is disseminating child marriage prevention programs, beginning with socialization on the negative impacts of child-age marriage. They need to have knowledge about maturing the age of marriage (PUP) and encouraging the importance of children (12-year compulsory education). Culturally, there is the term 'ragap papap' in Banjarmasin, which means a community figure who is embraced, so that is what is followed. However, there are community leader who "support" child marriage by falsifying the child's age so they can married by law.

4. Role of the Office of Religious Affairs (KUA), Religious Courts (PA) and Civil Registry. KUA has a program for prospective brides and grooms, named Suscatin program. The aim is to increase understanding and knowledge of household/family life and reducing the number of disputes, divorces and domestic violence. However, this implementation of the program was deemed ineffective. The program is still limited only about information on the roles of husband and wife, which is also gender bias with patriarchal perspective. In addition, the KUA, Religious Courts, and Civil Registry (for nonMuslims) must participate in socializing the existence of legal sanctions on illegal practices that support child marriage. Such as sanction parents, and religious/community leaders if they still officiate child marriage. In the FGDs, there was also the recounted experience of a KUA official, which took considerable attention, whereas a girls was forced to wed a much older man, and the girl did not understand the idea of consummation of marriage. Also in FGD, KUA said how community leaders and parents falsify document to marry off the child and KUA 'compelled' to accept it :

\footnotetext{
"There are still government officials who manipulate marriage administration at various levels. We cannot refuse if the registered documents are complete, although in appearance we can tell that the bride and groom are still children. For this reason, legal sanctions for individuals who marry off others even though they are not authorized are also necessary so that there is also no practice of under-hand marriage. " (FGD Dissemination of
}

Research Results of Child Marriage, 20 August 2018, Banjarmasin City).

Apart from the role of the KUA, the roles of the religious court (PA) and the civil registry are also quite important in preventing child marriages. The role of the PA is primarily in preventing prospective brides from filing a marriage dispensation letter. This is quite important considering that many parents also use this method in marrying their children even though they are not yet of age.

The Banjarmasin chapter of Aisyiyah Women's Organization. Aisiyah is one of the autonomous organizations for Muhammadiyah woman. As a social organization, Aisyiyah also focuses on health and environmental issues around women. Aisyiyah developed a center for service activities and improving the quality of public health and environmental conservation through education (www.muhammadiyah.or.id). In interview, Aisyiyah state their mission is to work directly with public, one of them is providing health education. What Aisyiyah have can be beneficial in therm of socializing impact of child marriage, through reproductive health issue. Also based on the interview, Aisyiyah also provides counseling from district level to PKK mother activities. One of the topic is risk of pregnancy if it occurs in child uterus. Aisyiyah provides socialization about the impact of child pregnancy in various ways and is easily understood by the community. In addition, Aisyiyah also advocate the impact of child marriage through community leaders so they will not provide letter approving the marriage. Aisyiyah also works alongside religious leaders to give opinions that marrying a girl with unwanted pregnancy will not solve the problem. Aisyiyah also conducts health training for mubaliq. In this case the preachers (ulama/ustadz/ustadzah) are role models for the community, so that the community in general will listen and obey what they talk about, as previously explained regarding the role of religious leaders.

\section{- Micro Level}

The most strategic actor at micro level is the family as ond of the expression of the FGD participants :

"The family is the closest party in relation to the children. How can the family educate and become the strongest defender?" (FGD for Dissemination of Research Results on 
Child Marriage, 20 August 2018, Banjarmasin City)

Education starts from the smallest social unit, family. According to Child Protection Law Family (parents/guardian) are obliged to provide and guarantee protection for the fulfillment of children's rights, including preventing the practice of child marriage. In some region child marriage is so common, one of the reason is because they afraid their daughter become spinster if not married fast. The following section provides an explanation of this phenomenon:

Family Role (Grandmother and Mother); First, Grandmother (mostly wife's parents) is the most decisive actor in the family with traditional culture of south kalimantan. The grandmother is usually around mid 40- mid 50 and still helps with family economy. She determined various aspect, such as the decision to marry off the child, determined the matchmaking, and she also hold decision when the child got proposed (use 'membalu - balu' action, 'just marry first, even when one ends up a widow its fine,'), The culture idea about spinster still influence this particular thing in the community.

Second, the role of the mother is more dominant than that of the father in making the decision to marry off the child. There are ideas in general, one, children are considered to be a burden on the family if they do not work or go to school, second, culture of "when the child has menstruated, she should be married off as soon as possible" and that of "it is fine to be divorced". These two idea seems legitimize the practice of child marriage in the village/district level. In addition, in FGD also state, how similar to grandmother, the myth of 'spinster' is also haunting the mother to marry off their daughter even if they are very young. Besides sinister, they are also afraid their children engage in risky teenage associations which can lead to sexual intercourse and unwanted pregnancy. After all, marrying off their children is the best way out for the family rather than enduring disgrace.

\section{CONCLUSIONS}

$\mathrm{V}$ arious efforts on the role of strategic social actors from the macro, mezzo, and micro levels in preventing the practice of child marriage in South Kalimantan Province have basically been clearly mapped. However, the actors at the three levels have not been synergized. Likewise, the handling of several cases of child marriages have not been focused. Actors from each level are still working on their own according to their 'program', so that the impact of preventing the practice of child marriage at the implementation stage is not yet visible. This was admitted by the Head of Bappeda of South Kalimantan Province who was of the opinion that the prevention or handling of cases of the practice of child marriage in South Kalimantan Province has not been carried out in a holistic and integrated manner. Each of the main levels at the macro and mezzo levels, consisting of local government and regional apparatus organizations (OPD) related to handling this issue, has not yet implemented the HITS method (Holistic, Integrative, Integrated, Spatial). In general, the budget allocation remains money follows function (budget allocation using a functional approach) not money follows program (prioritizing selection to fund priority programs/activities), in which everyone feels that 'their' program and work are the most important.

Thus, it is necessary to create synergy between institutions or agencies and related OPD, to jointly make the issue of the practice of child marriage as one of the strategic and priority issues in South Kalimantan. Moreover, since 2011, South Kalimantan Province has also had a policy in the form of a Regional Regulation on Gender Mainstreaming, which can also be linked to policies on the Prevention of the Practice of Child Marriage. In other words, if at the macro level the policies and budgets are clear, it will make it easier for cooperation between mezzo and micro levels as an extension of the government to jointly prevent the practice of child marriage on a more massive basis, as has been done by the women's organization Aisyiyah. The organization, which works from the mezzo level to the micro level by socializing impacts of child marriage through the approach of reproductive health in particular, also including the impact of a pregnancy at a young age to the PKK, to the level of the village head, district head and religious figures in its organizational network, can be a good practice that can be followed by other community organizations that also care about the issue of protecting children and women, specifically for the prevention of child marriage in South Kalimantan Province, which in 2020, based on BPS 2019 data, again ranks as the province with the highest occurrence of child marriage. ${ }^{1}$

\footnotetext{
${ }^{1}$ The proportion of women aged 20-24 who were married before the age of 18 , by province, in 2019 was highest in South Kalimantan with a percentage of $21.2 \%$, while the national average was $10.82 \%$ (BPS, 2020).
} 


\section{E. ACKNOWLEDGMENT}

ur gratitude goes to PKBI South Kalimantan (Banjarmasin) for assisting the research process in the field, as well as stakeholders and informants from government elements (Bappeda South Kalimantan Province, Ministry of Religion Regional Office), as well as the provincial nongovernmental organization LPA (Child Protection
Agency), Aisyiyah Women's Organization, Provincial Children's Forum, and other parties that cannot be mentioned one by one. Further, our gratitude goes to the Ministry of Research, Technology and Higher Education who has provided funding for research, as well as FISIP UI and the Gender and Sexuality Study Unit of the LPPSP FISIP UI as part of the research team.

\section{REFERENCES}

Badan Pusat Statistik. (2016). Data Susenas 2016. Badan Pusat Statistik.

Badan Pusat Statistik. (2017). Perkawinan Usia Anak di Indonesia 2013 dan 2015 Edisi Revisi. In Badan Pusat Statistik.

Benedicta, G. D., Noor, I. R., Kartikawati, R., Zahro, F. A., Susanti, L. R., Natih, N. N. S., \& Ramadhan, F. R. (2017). Studi Kualitatif 'Yes I Do Alliance'(YID). Faktor Penyebab Dan Konsekuensi Perceraian Setelah Perkawinan Anak Di Kabupaten Sukabumi, Rembang Dan Lombok Barat.

Djamilah \& Kartikawati. (2014). Dampak Perkawinan Anak di Indonesia. Jurnal Pemuda, Vol.3 No.1.

Hidayana, M. I. et. al. (2018). Rekonstruksi Tafsir Sosial Politik Atas Perkawinan Anak.

Kustini. (2013). Menelusuri Makna di Balik Fenomena Perkawinan di Bawah Umur dan Perkawinan tidak Tercatat. Jakarta: Puslitbang Kehidupan Keagamaan.

Pakasi, D. et. al. (2018). Situasi Perkawinan Anak, Kehamilan Remaja, dan Sunat Perempuan di Kabupaten Sukabumi, Rembang, dan Lombok Barat (Studi Midline 2018).

Statistik, B. P., \& UNICEF. (2016). Kemajuan yang tertunda: analisis data perkawinan usia anak di Indonesia. In Badan Pusat Statistik dan UNICEF.

Wirutomo, P. (2014). Mencari Makna Pembangunan Sosial: Studi Kasus Sektor Informal di Kota Solo. Masyarakat: Jurnal Sosiologi, 101-120.

Wulandari, Dwi Anggi, Marzuki. (2020), Undang-undang Simbur Cahaya Dalam Mengatur Hukum Perkawinan Di Kesultanan Palembang. Jurnal Antropologi: Isu-isu Sosial Budaya - Vol. 22 No. 02 (December 2020).

Yulkardi, Jelly, Yunarti (2020), Pernikahan Usia Anak: Manifestasi Disfungsi Sistim Tali Tigo Sapilin Dalam Masyarakat Di Nagari Sialang, Kabupaten 50 Kota, Sumatera Barat, Jurnal Antropologi: Isu-isu Sosial Budaya - Vol. 22 No. 02 (December 2020)

\section{Websites:}

"Stop Early Marriage:" Happiness for a Moment, Suffering for a Lifetime", https://www.kompasiana.com/menix/57b446e9a123bd9b162a1d29/stop-pernikahan-dini-kebahagiaan-sesaatsengsara-sepanjang-masa?page=all; accessed 20.20, 15/10/18.

Regulation of the Director General of Islamic Community Guidance Number: DJ.II/542 of 2013 concerning the Guidelines for Pre-Marriage Course

Law Number 16 of 2019 concerning Amendments to Law Number 1 of 1974 concerning Marriage 